\title{
УДК 615.21
}

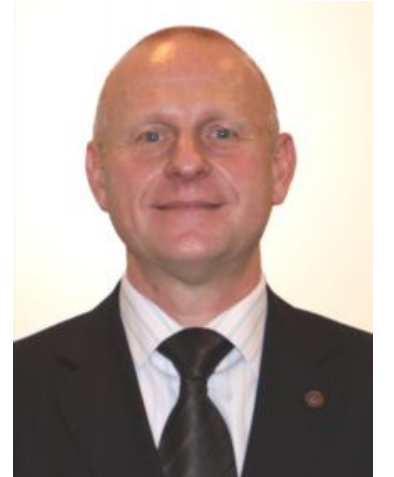

В. В. ШАПОВАЛОВ,

о-р фарм. наук, проф., начальник відділу фармації управління медичної та фармацевтичної діяльності Департаменту охорони здоров'я ХОДА;

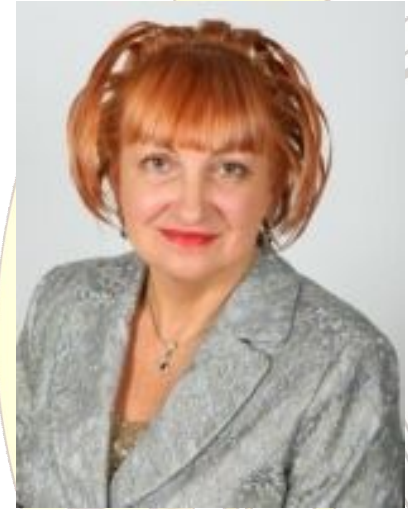

В. О. ШАПОВАЛОВА, д-р фарм. наук, проф., завідувач кафедри медичного та фармацевтичного права, загальної і клінічної фармацї, Харківська медична академія післядипломної освіти, м. Харків

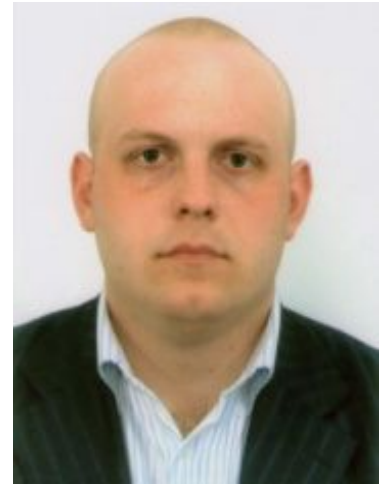

В. В. ШАПОВАЛОВ, канд. фарм. наук, доцент кафедри медичного та фармацевтичного права, загальної і клінічної фармації, Харківська медична академія післядипломної освіти, адвокат;
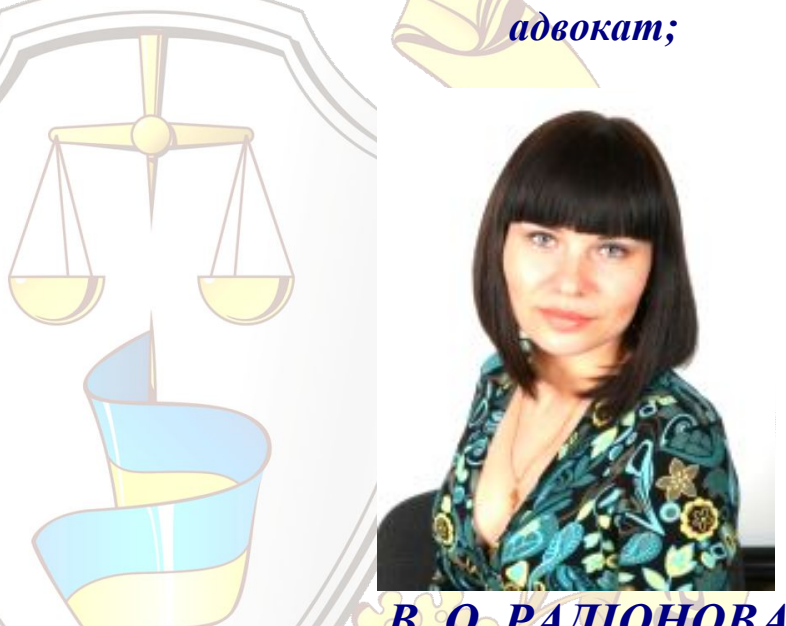

В. О. РАДІОНОВА, канд. фарм. наук, доцент кафедри медичного та фармацевтичного права, загальної і клінічної фармації, Харківська медична академія післядипломної освіти, м. Харків

\section{СУДОВО-ФАРМАЦЕВТИЧНЕ ТА КРИМІНАЛІСТИЧНЕ ВИВЧЕННЯ ФАКТІВ УБИВСТВ, СКОСНИХ ЖІНКАМИ У СТАНІ АЛКОГОЛЬНОГО СП'ЯНІННЯ}

Проведено судово-фармацевтичний аналіз фактів убивств, скоєних жінками у стані алкогольного сп'яніння на криміналістичних засадах. Встановлено, щуо вирішення проблеми алкоголізму як серед чоловіків, так і жінок в Україні знаходиться у площині вдосконалення законодавства щзодо обмеження доступу до алкоголю всіх верств населення за прикладом мусульманських країн. Крім того, потребують подальшого розвитку міждисциилінарні зв'язків між кримінальним правом, криміналістикою, медичним і фармацевтичним правом.

Ключові слова: судова фармація, криміналістика, убивство, жінка, алкоголь.

(С) Шаповалов В. В., Шаповалов В. В., Шаповалова В. О., Радіонова В. О., 2015 
Споконвіку в Україні жінка вважається берегинею домашнього вогнища, добробуту, спадщини, дитячого здоров'я та генофонду нації, тобто основою здорової сім’ї і суспільства. Саме від стану здоров'я жінки залежить здоров'я кожної окремої сім’ї та суспільства в цілому. Проте протягом останніх десятиліть, під час становлення гендерного рівноправ'я, роль жінки істотно змінилася: 3 матері та берегині домашнього вогнища вона перетворилася на активного суспільного діяча, який відчуває високий фізичний та психологічний тиск. Щоб працювати на рівних з чоловіками, жінка починає вживати тютюнові вироби та алкогольні напої, а також інші психоактивні речовини (лікарські препарати, наркотичні засоби, психотропні, сильнодіючі речовини, далі - ПАР), унаслідок чого у неї з'являються розлади здоров'я (алкоголізм, наркоманія, ВІЛ/СНІД та ін.) [32].

За результатами досліджень І. К. Сосіна, І. В. Лінського, О. І. Мінко, П. В. Волошина, Н. О. Марути, Ю. Ф. Чуєва, А. В. Мельник на прикладах 3 клінічної практики доведено, що жіночий організм слабкіший за чоловічий та, на відміну від останнього, не звик до тривалого й надмірного зловживання алкоголем (пиво, горілка, вино тощо) [29-31]. Саме тому звикання до ПАР у жінок відбувається швидше, ніж у чоловіків, поведінка у стані алкогольного сп'яніння - агресивніша, а лікування жіночого алкоголізму та наркоманії триваліше і важче. На жаль, приклади із судово-фармацевтичної практики свідчать, що жінка внаслідок зловживання ПАР та у стані алкогольного сп'яніння вчинює протиправні дії, що є кримінальними злочинами, внаслідок чого страждають іiі рідні та діти, а держава несе соціальне навантаження та великі матеріальні збитки, направлені на іiі лікування та забезпечення лікарськими засобами (ЛЗ) всіх класифікаційно-правових груп (КПГ). Слід відмітити, що КПГ ЛЗ - це група, що вказує на профіль безпеки дії ЛЗ на організм пацієнта, який залежить від номенклатурно-правової, клінікофармакологічної груп і визначає режим контролю [24].

Метою статті є судово-фармацевтичне та криміналістичне вивчення наслідків алкоголізації жінок на основі аналізу статичних даних ВООЗ та () Шаповалов В. В., Шаповалов В. В., Шаповалова В. О., Радіонова В. О., 2015 
Департаменту охорони здоров'я Харківської ОДА щодо захворюваності на алкоголізм у країнах - членах Свропейського Союзу (ЄС) та рівня вживання алкоголю жінками в Україні; випадків із судово-фармацевтичної практики, пов'язаних із вбивствами, скоєними жінками у стані алкогольного сп'яніння; узагальнення нормативно-правових актів для надання пропозицій щодо зменшення рівня обігу алкогольних напоїв і підвищення рівня доступності для жінок певних груп ЛЗ.

Матеріалами дослідження стали статистичні дані МВС України, Європейського бюро ВОО3; наукові статті у фахових періодичних виданнях та в мережі Internet; конкретні приклади з судово-фармацевтичної практики; діючі нормативно-правові акти (НПА) України та Російської Федерації, що регулюють обіг алкогольних напоїв і тютюнових виробів, інші НПА у сфері охорони здоров'я. Під час виконання роботи використовувався метод спостереження, нормативно-правовий, судово-фармацевтичний, судовонаркологічний, судово-медичний та судово-психіатричний аналіз.

Нами було проаналізовано статистичні дані ВООЗ за 2010 р. щодо вживання алкоголю жінками у віці 15-19 років у країнах Свропи (рисунок).

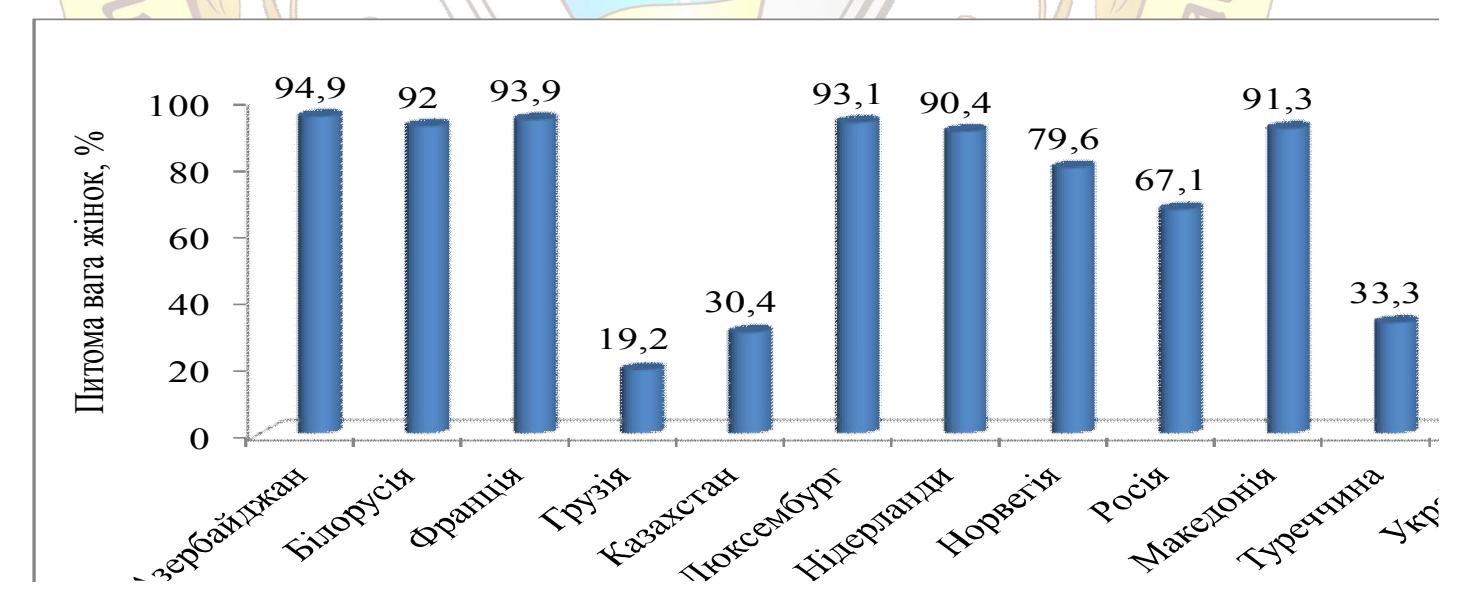

Рисунок. Питома вага жінок (15-19 років), які вживають алкоголь, в різних країнах Європи

Судово-фармацевтичний аналіз показав, що за питомою вагою жіночої алкоголізації країни ЄС розподілені на три групи [17]: 1) країни $з$ високим рівнем вживання алкоголю жінками; 2) країни з середнім рівнем вживання (С Шаповалов В. В., Шаповалов В. В., Шаповалова В. О., Радіонова В. О., 2015 
алкоголю; 3 ) країни з низьким рівнем вживання алкогольних напоїв. До першої групи віднесено 7 країн, де рівень вживання алкоголю жінками складає від 79,6 до 94,5 \% (Азербайджан, Білорусь, Франція, Люксембург, Нідерланди, Норвегія та Македонія); до другої - Росію, Україну, Туреччину; до третьої - Грузію та Казахстан.

О. І. Мінко зазначає, що дослідження ВООЗ свідчать про зростання проблеми алкоголізації, що пояснюється збільшенням кількості алкоголю, споживаного на душу населення [18]. За експертними оцінками загальне споживання в літрах абсолютного алкоголю в Україні становить 11-12 л і відповідає показникам таких європейських країн, як Іспанія (12,8 л), Німеччина (12,9 л), Австрія $(11,4)$. Лідирують Угорщина (19 л), Росія (16 л), Португалія $(14,7$ л) [18].

Крім шкоди для організму жінок, що зловживають алкоголем, наслідки його непомірного вживання мають шкоду для оточуючих (чоловік, діти, батьки, співробітники та ін.). Слід відмітити, що в країнах СС, за даними ВОО3 за 2004 р., причиною 5500 випадків смерті серед чоловіків і понад 2000 випадків смерті серед жінок було вживання алкоголю іншими особами [9], тобто у переважній більшості, смертельні наслідки i каліцтва були дорожньо-транспортний травматизм, на другому місці - насильство. У Південній Європі алкоголь займає найбільшу частку серед причин смертності для даного регіону. Проте у Центрально-Східній та Східній Європі розрахунки показали, що дорожньотранспортні пригоди, пов’язані із вживанням алкоголю, частіше завдають шкоди саме нетверезим водіям. У країнах СС з уживанням алкоголю щорічно пов’язано близько 120000 випадків передчасної смерті - кожен 7-й випадок серед чоловіків і кожен 13-й серед жінок [22]. У свою чергу, як відзначає Н. Левчук, у 2007 р. смертність, пов’язана із вживанням алкоголю, в Україні склала 40 \% всіх смертей серед дорослих чоловіків і $22 \%$ - серед жінок [21].

Судово-фармацевтичний аналіз стану та структури злочинності в Україні, пов’язаної з умисними вбивствами (та замахами), за 10 місяців 2012 р. у порівнянні з аналогічним періодом 2011 р. свідчить про те, що найбільшу (С Шаповалов В. В., Шаповалов В. В., Шаповалова В. О., Радіонова В. О., 2015 
кількість вбивств скоєно у Донецькій - 261 (динаміка зменшення -11,8 \%), Харківській - 180 (динаміка зменшення -3,2 \%), Дніпропетровській - 145 (динаміка збільшення $+15,1 \%$ ), Луганській - 127 (динаміка зменшення -8,1\%) обл. та АР Крим - 91 (динаміка зменшення -16,5 \%); а найменшу - у Волинській - 14 (динаміка зменшення -56,3 \%), Тернопільській - 19 (динаміка збільшення $+18,8$ \%), Чернівецькій -17 (динаміка зменшення $+41,7 \%$ ) обл.; у всіх інших областях - середній рівень, що знаходиться у межах від 20 (ІваноФранківська обл., динаміка 0; Рівненська обл., - 22 злочини, динаміка $+22,2$ \%) до 95 (Київська обл., динаміка збільшення $+26,7$ \%; Одеська обл., динаміка збільшення $+10,5 \%$ ).

За результатами судово-психіатричних досліджень I. В. Лінського, О. I. Мінко та Вал. В. Шаповалова встановлено причинно-наслідкові зв'язки та прямо пропорційну залежність між кількістю алкогольних психозів, наркотоксикоманій і кількістю скоєних злочинів на території України взагалі та в Харківській області зокрема [23]. Тобто жінки, що мають прояви алкогольної залежності, надмірно та тривало вживають ПАР (алкоголь), найбільш часто виступають жертвами або злочинцями у правопорушеннях, що скоюються у стані алкогольного сп'яніння. Виявлений причинно-наслідковий зв'язок у ланцюзі «особа - схильність до алкоголізму - надмірне вживання алкоголю (алкогольна хвороба) - злочин у стані алкогольного сп'яніння - наслідки для злочинця та жертви» підтверджується прикладами із судово-фармацевтичної практики (приклади 1-3).

Приклад 1. Суддею Козятинського міського районного суду Вінницької області визнано жінку винною у вчиненні кримінального злочину, передбаченого 4. $1 \mathrm{~cm} .115$ (умисне вбивство) Кримінального кодексу (КК) України і оголочено ій вирок - 8 років позбавлення волі [5]. Під час судового слідства встановлено, що у січні 2014 р. пращівники мілічії Козятинського МВ УМВС України у Вінницькій області затримали 37-річну гр. А., жительку с. Спиченці, яка, знаходячись у стані алкогольного сп'яніння, під час сімейного конфлікту та неприязних стосунків з гр. Б., щзо раптово виникли на фоні алкогольного сп'яніння, задушила свого співмешкания. Як пояснила гр. А. слідчому, під час проведення відтворення обставин подій з використанням відеозйомки, в день скоєння вбивства вона повернулась додому у стані алкогольного сп'яніння, 
після дорікань чоловіка, в результаті яких між подружжям виникли неприязні відносини, схопила його за иию руками $i$ не відпускала, доки він не знепритомнів. Під час досудового слідства гр. А. проведено судовофармацуевтичну, судово-медичну, судово-криміналістичну, судово-наркологічну та судово-психіатричну експертизи, якими було повно, об' єктивно та всебічно доведено умисний мотив злочину.

Приклад 2. Слідчим СВ Кіровоградського МВ УМВС Украӥни в Кіровоградській області відкрито кримінальне провадження за ч. $1 \mathrm{~cm} .115$ (умисне вбивство) КК України стосовно мешканки м. Кіровоград гр. Ю., 31 рік [7]. В ході досудового слідства встановлено, щзо 17.11.2014 р. на телефонну лінію «102» Кіровоградського МВ надійшло повідомлення від працівників швидкої медичної допомоги про те, щзо у квартирі за місчем виклику в м.Кіровоград під час надання медичної допомоги виявлено тіло чоловіка 3 ножовим пораненням. На місче подї негайно виїхала слідчо-оперативна група міськвідділу міліції у складі: слідчий, експерт-криміналіст, судово-медичний експерт та оперативний працівник карного розшуку для з'ясування обставин злочину. У ході огляду місчяя події виявлено тіло 51-річного гр. Ж. з ножовими пораненнями та знаряддя злочину - кухонний ніж зі слідами крові, який було вилучено та направлено до НДЕКЦ для проведення експертизи. Під час опитування свідків було встановлено, щзо напередодні сім'я постраждалого святкувала його день народження, де всі присутні вживали у великих кількостях алкогольні напої. Свідки вказали, щуо у розпал святкування між гр. Ж. та його дружиною, 31-річною гр. Ю., виникла суперечка на побутовому грунті, яка швидко перейшли в неприязні відносини, у відповідь на ненормативну лексику гр. Ж. в адресу дружини, гр. Ю. схопила рукою ніж раптово вдарила його в область серчя. Від отриманих поранень гр. Ж. помер на місиі. Слідчим було призначено проведення судово-фармацевтичної, судовомедичної, судово-криміналістичної, судово-наркологічної та судовопсихіатричної експертиз. За скоєний злочин гр. Ю. затримана, досудове слідство триває.

Приклад 3. Первомайським районним судом Харківської області було визнано гр. 3., 47 років, мешканку с. Павлівка Кегичівського району, винною у злочині, передбаченому ч. 1 cm. 115 (умисне вбивство) КК України та на підставі cm. 69 КК України винесено вирок - б років позбавлення волі [6]. В ході досудового слідства встановлено, щуо на телефонну лінію «102» Кегичівського РВ ГУМВС України в Харківській області надійшло повідомлення від фельдшера Павлівського фельдшерського-акушерського пункту КЗОЗ Кегичівської ЦРЛ про те, щзо він надав медичну допомогу за місцем мешкання пацієнту із різаною раною грудної клітини. На місие злочину прибула оперативно-слідча група, у складі: слідчий, експерт-криміналіст, судовомедичний експерт та оперативний працівник карного розиуку, під час якого було складено протокол місчяя пригоди та вилучено речові докази (пляшки з-під алкогольних напоїв, плями крові, кухонний ніж тощо), а також застосовано відео- та фотозйомку. Слідчим складено план невідкладних слідчих дій та

(С Шаповалов В. В., Шаповалов В. В., Шаповалова В. О., Радіонова В. О., 2015 
оперативно-розиукових заходів, розпочато слідство, під час якого внаслідок допиту гр. 3. було встановлено, щуо вона проживала з гр. В. тривалий час в одному домоволодінні. Увечері, повернувиись додому після роботи, вона побачила, щзо гр. В. разом з іншою жінкою вживає спиртні напої, та на ї̈ думку, між ними були статеві відносини. У результаті чого у гр. 3. до гр. В. виникли неприязні відносини, вона допила залишки алкогольних напоїв за своїм чоловіком, а в цүей час жінка схаменулася $і$ побігла з хати. У свою чергу гр. 3. схопила кухонний ніж та нанесла гр. В. удар в область грудини, чим завдала йому тяжкі тілесні ушкодження. Потерпілого було госпіталізовано до Кегичівської ЦРЛ, де він помер від тілесних ушкоджень, несумісних із життям.

Наведені типові приклади 3 судово-фармацевтичної, судово-медичної, судово-наркологічної практики свідчать про те, що усі злочини були вчинені не навмисно, без попереднього планування та злочинного зговору з будь-ким, а випадково - під час сварок, що виникали раптово у осіб, які знаходилися в стані алкогольного сп'яніння. При цьому вік убивць варіює від 31 до 47 років. У першому випадку в якості знаряддя убивства був використаний задушливий фактор рук, у другому та третьому - кухонний ніж (підручний засіб). В усіх справах слідчими призначено плани слідчих дій та оперативно-розшукових заходів, проведено судово-медичну, судово-фармацевтичну, судовокриміналістичну, судово-психіатричну, судово-наркологічну експертизи. В результаті проведених експертиз було встановлено, що всі зловмисники та жертви на час скоєння злочинів знаходилися у стані сильного алкогольного сп'яніння, а алкогольним напоєм у всіх випадках була горілка. Жоден із злочинців або жертв в наведених прикладах не знаходився на обліку у сімейних лікарів, лікарів-психіатрів або наркологів, що вказує на необхідність посилення медичної опіки з боку лікарів загальної практики - сімейної медицини, наркологів і психіатрів у ланцюзі правовідносин «лікар - пацієнт - провізор». Отже, жінки із схильністю до зловживання алкогольними напоями потребують контрольованої з боку лікаря та провізора фармакотерапії для зменшення рівня вживання алкогольних напоїв та мінімізації наслідків такого зловживання (конфлікти, депресії, болі різного генезу, алкоголізм, наркоманія та супутні захворювання). Дані ВООЗ також підтверджують, що саме через низьку 
доступність деяких груп ЛЗ велика кількість жінок має проблеми з аналгезією, вирішення яких знаходить у надмірному вживанні алкогольних напоїв (часто разом $з$ тютюном та ін. ПАР), що часто призводить до конфліктних ситуацій та виникнення неприязних відносин у сім'ї, на роботі [16; 33].

У зв'язку з цим вважаємо за необхідне наголосити на важливості забезпечення певних категорій громадян регулярним безоплатним проходженням медичних оглядів з обов'язковими аналізами крові та сечі на наявність ПАР та продуктів їхнього розпаду. В свою чергу це вимагає внесення доповнень до ст. 17 («Обов'язкові медичні огляди працівників певних категорій») Закону України «Про охорону праці» [41], а саме забезпечення безоплатним обов'язковим періодичним медичним оглядом: жінок, що знаходяться у декретній відпустці та відпустці по догляду за дитиною [34]; безробітних; соціально незахищених категорій населення [35-40]. При цьому проходження таких медоглядів має відбуватися за рахунок роботодавця, а для осіб, що не мають роботи - за рахунок держави - відповідних регіональних департаментів (управлінь) соціального захисту.

Важливим моментом $\epsilon$ попередження вчинення злочинів у стані алкогольного сп'яніння і провідну роль тут відіграє саме рання діагностика та лікування стресів, зняття психологічного й фізичного навантаження у жінок, власне чим, на нашу думку, повинні займатися сімейні лікарі. У свою чергу, під час розслідування кримінальних справ слідчий, організовуючи проведення експертиз, має додатково запрошувати комісію лікарів: наркологів, психіатрів, невропатологів - для виявлення у злочинців ознак алкогольних психозів, алкогольного делірію та інших психічних розладів, пов'язаних 3 надмірним вживанням алкоголю; також необхідно створити умови для проведення стаціонарних медичних оглядів 3 використанням необхідного медичного обладнання, техніки, ЛЗ та процедур на базах бюро судово-медичної експертизи, спеціалізованих лікувальних закладів.

На думку А. В. Кофанова, найважливішим завданням оперативнорозшукових та слідчих органів $\epsilon$ швидке розкриття вбивств, встановлення (ㄷ Шаповалов В. В., Шаповалов В. В., Шаповалова В. О., Радіонова В. О., 2015 
причин і умов, що сприяють їх вчиненню [1]. Складність розслідування вбивств зумовлена, як правило, великою кількістю свідків, версій розслідування, характером речових доказів, а в деяких випадках інсценуванням обставин події злочину. Ефективному розслідуванню злочинів сприяє з’ясування даних, що складають криміналістичну характеристику вбивств. До елементів криміналістичної характеристики вбивств відносяться: спосіб вчинення вбивства; спосіб приховування; час, місце і обставини події злочину; «слідова картина» події; особа злочинця; особа потерпілого.

Методика розслідування окремих видів злочинів, як стверджує В. Ю. Шепітько, є важливим розділом криміналістики. Тобто криміналістична методика - це система наукових положень i розроблюваних на їх основі рекомендацій щодо організації і здійснення розслідування та запобігання окремих видів злочинів. Окрема методика розслідування - це система взаємопов'язаних і взаємообумовлених дій. Тому іiі завданням є розроблення типових систем дій слідчого, що сприяють обранню оптимальної лінії поведінки в процесі розслідування певного виду злочину. Окрема криміналістична методика - це комплекс порад типізованого характеру, що $\epsilon$ найбільш ефективним при розслідуванні того або іншого виду (роду) злочинів: крадіжок, вимагань, вбивств, бандитизму і т.п. Криміналістична методика при розробленні відповідних рекомендацій широко використовує кримінальноправові, кримінологічні та кримінально-процесуальні дані. Інформаційними джерелами криміналістичної методики є:巳 наукові положення теорії криміналістики, дані інших наук, наприклад, судової фармації або судової медицини, результати узагальненого досвіду слідчих органів, норми відповідних законодавчих та інших нормативних актів [2].

Важливим є проведення досудового слідства та виконання плану щодо розслідування убивства, правильна оцінка та значення слідчих дій під час розслідування кожного вбивства, i, як наголошує В. Я. Тацій, вагомість їх полягає в тому, що слідчі дії є основним способом збирання доказів і звідси основним засобом всебічного, повного та неупередженого дослідження всіх

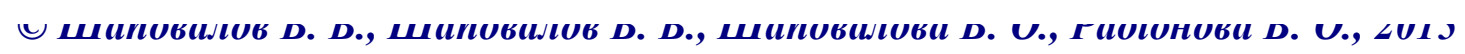


обставин кримінального провадження, досягнення його завдань [3]. Закон передбачає проведення такої послідовності слідчих дій, щоб вони вирисовували схему злочину та надавали можливість слідчому тримати під контролем весь процес оперативно-розшукових заходів, а саме: допит, в т.ч. одночасний допит двох чи більше вже допитаних осіб (статті 224-226 Кримінальнопроцесуального Кодексу України); пред'явлення для впізнання: особи (ст. 228 КПКУ), речей (ст. 229 КПКУ), трупа (ст. 230 КПКУ); обшук (статті 233-236 КПКУ); огляд: місця події, приміщень, речей, медикаментів та документів (ст. 237 КПКУ), трупа та одягу (ст. 238 КПК), огляд трупа, пов'язаний 3 ексгумацією (ст. 239 КПКУ); слідчий експеримент (ст. 240 КПКУ); огляд особи (ст. 241 КПКУ); залучення експерта та проведення судово-медичної, судовофармацевтичної, криміналістичної та ін. експертиз (статті 242-243 КПКУ) [42]. Саме від рівня професійної підготовки та внутрішніх переконань слідчого і прокурора під час складання плану слідчих дій, проведення експертних досліджень (тобто які з них і в якій послідовності будуть проведені), від конкретних обставин кримінального провадження або заявлених клопотань стороною захисту залежатиме якість та швидкість проведення розслідування та розкриття злочину. Проте, на нашу думку, важливим початком розслідування $є$ кваліфікований огляд місця злочину, реєстрація кримінальної справи, складання плану слідчих дій та оперативно-розшукових заходів, допит свідків, проведення судово-медичної експертизи тощо.

Ми погоджуємося 3 В. I. Борисововим, який зазначає, що вплив на формування кримінально-правової норми має саме слідча та судова практика [44]. Це означає, на нашу думку, те, що слідчий та прокурор, розслідуючи кримінальні справи, або суддя при розгляді кримінальної справи про убивства або незаконний обіг ПАР (алкоголь, наркотичні засоби, отруйні, сильнодіючі, психотропні речовини, прекурсори тощо), повинні всебічно, повно та об'єктивно розглянути і встановити причини та умови, що цьому сприяли. Повинні звернутися 3 відповідним поданням (3 пропозиціями щодо удосконалення законів або нормативно-правових актів, протоколів лікування

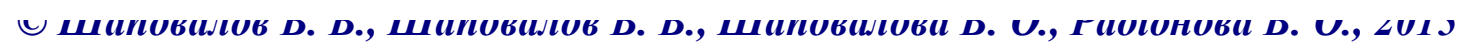


тощо) до органів державної та місцевої влади і місцевого самоврядування. Саме медичне i фармацевтичне право $\epsilon$ міждисциплінарною наукою, що тісно пов'язана 3 кримінальним правом i криміналістикою. Вивчаючи конкретні факти неналежного надання медичної і фармацевтичної допомоги, що призвело до смерті (медичні та фармацевтичні помилки); злочини про вбивства, отруєння, розбійні напади та інші правопорушення, пов’язані із застосуванням ПАР (в т.ч. спайсів, курильних сумішей, солей для ванн тощо), або їх незаконним обігом, медичне і фармацевтичне право сприяє донесенню до фахівців важливої інформації про конкретні злочини. Тим самим дає можливість підвищення професійного рівня, уникнення в подальшому порушення законодавства та попередження скоєння злочинів, а також внесення відповідних змін і доповнень до законів України. Це сприятиме підвищенню рівня захисту прав громадян та пацієнтів, що страждають різними розладами здоров’ я, в т.ч. внаслідок вчинених злочинів, що є порушенням чинних Законів України, постанов Кабінету Міністрів України та наказів Міністерства охорони здоров’ я України $[11 ; 14 ; 33-36 ; 39]$.

Розробка трактування кримінальним правом міждисциплінарних категорій і понять, як відмічає М. І. Панов, виступає науковою і нормативноправовою основою для інших наук цього блоку (судової фармації, фармацевтичного та медичного права тощо) [43]. Безумовно, тут мають місце відносини субординації, відповідно до яких прикладні науки цього блоку при розробці відмічених категорій i понять, як i юридичних (медичних, фармацевтичних, економічних та ін.) термінів, мають виходити 3 основних i принципових положень науки кримінального права. При цьому викладене зовсім не виключає розробку міждисциплінарних проблем прикладними науками з урахуванням особливостей їх об’єкта і завдань кожної з наук (між кримінальним правом та медичним і фармацевтичним правом). Але основні й суттєві ознаки зазначених категорій i понять у цих науках повинні бути похідними від основних і суттєвих ознак, що розробляються і формулюються наукою кримінального права, з одного боку, та медичного (судова медицина, 
судова наркологія, судова психіатрія) i фармацевтичного права (судова фармація), з іншого.

Кримінальні прояви насильства виявляються, насамперед, у таких формах насильства, зазначає Є. С. Тонков, як умисні вбивства і заподіяння тяжкої шкоди здоров’ю [4]. Тенденції розвитку рівня злочинності протягом минулих десятиліть неухильно і прискорено погіршувалися, а ii сучасний рівень зовсім не $\epsilon$ несподіванкою. Аналіз насильницької злочинності свідчить про такі негативні тенденції, як зростання жорстокості, широке використання вогнепальної та холодної зброї, поширення замовних і ненавмисних вбивств, почастішання випадків захоплення заручників i, нарешті, прояв агресії як самоцілі. Характеристика злочинності дозволяє виділити наступні негативні тенденції: кількісне зростання злочинності в цілому; значне збільшення в структурі злочинності частки тяжких та особливо тяжких злочинів; істотна зміна мотиваціï протиправної поведінки (широке поширення корисливих злочинів); переважання серед злочинців осіб без постійного джерела доходу, що тісно пов'язане 3 різкою диференціацією населення за майновим станом, обумовленої триваючими кризовими соціально-економічними процесами; збільшення відносного питомої ваги злочинності неповнолітніх (при цьому часто знаходяться під впливом ПАР). Законослухняне населення країни не відчуває своєї безпеки, не відчуває себе захищеним від злочинних посягань, що відбивається на загальному кліматі довіри по відношенню до держави. Правоохоронні органи в державному механізмі займають специфічне місце в силу покладених на них завдань по боротьбі зі злочинністю, охороною громадського порядку, забезпеченням безпеки громадян. Для цього вони наділені особливими державно-владними повноваженнями, підкріпленими необхідними засобами і методами примусу, прийомами силового впливу на правопорушників аж до застосування вогнепальної зброї.

У країнах з переважним споживанням міцних спиртних напоїв (горілка, коньяк тощо), при рівних кількостях прийнятого на душу населення абсолютного етанолу, рівень пов'язаних 3 алкоголем проблем зі здоров'ям (С Шаповалов В. В., Шаповалов В. В., Шаповалова В. О., Радіонова В. О., 2015 
(алкоголізму, алкогольних психозів, цирозу печінки, смертності працездатного населення і т.п.) істотно вище, ніж в тих державах, де населення віддає перевагу вину або пиву, - стверджує I. В. Лінський [15]. Спеціальними дослідженнями, проведеними в 1991-1992 pp. і 2001-2002 pp. в США, доведено, що ризик розвитку алкогольної залежності сильно залежить від віку, в якому відбулася перша спроба вживання алкоголю. Чим раніше відбувається знайомство людини зі смаком спиртного, тим цей ризик вище. 3 результатів дослідження випливає, що у людей, які почали вживати алкоголь у віці до 15 років, ризик формування алкогольної залежності в 4 рази вище, ніж у тих, хто долучився до спиртного у віці 20 років або більше. Факторами, які визначають головну роль у формуванні тяги до алкоголю, $є$ матеріальне благополуччя, рівень культурного розвитку людини, наявність стресових ситуацій, завантаженість інформацією, сучасний темп життя. Однак генетична схильність займає не останне місце в схильності до зловживання алкоголю. Психологічні особливості особистості (стійкість до стресових ситуацій, занижена самооцінка, невпевненість у собі і т.п.) сприяють розвитку тяги до спиртного. У дітей, чиї батьки випивають, 3 дитинства формується переконання, що пити - це нормально. Тому вже років 3 десяти, якщо не раніше, у них відбувається перше знайомство $з$ алкогольними напоями.

У жінок споживання алкоголю пов'язане з більшим ризиком для здоров’ я, ніж у чоловіків, зазначає керівник програми «Алкоголь та заборонені наркотики» Європейського Регіонального Бюро ВОО3 Л. Моллер [1]. У жіночому організмі міститься менше води, ніж в чоловічому, тому концентрація в ньому алкоголю - а значить і ступінь його токсичності - буде вищою. Більше того, організм жінки виробляє менше ферментів, які розщеплюють алкоголь, і тому для виведення алкоголю з організму потрібно більше часу.

Однією із найбільш важливих проблем судової психіатрії на сьогодні залишається проблема гострих алкогольних психозів, - говорить Мельник А.В., - під час яких хворі вчинюють переважно тяжкі суспільно небезпечні дії (СНД), (С) Шаповалов В. В., Шаповалов В. В., Шаповалова В. О., Радіонова В. О., 2015 
спрямовані проти життя та здоров’я особи. За даними сучасних науковців, під час вчинення виражених агресивних дій (вбивство, тяжкі тілесні ушкодження) алкогольне сп’яніння спостерігається у 72 \% випадків, а в осіб із синдромом залежності від алкоголю рівень агресивної поведінки $є$ дуже високим та становить від 50 до $60 \%$ [12].

Аналіз літератури з наркології та епідеміологічних досліджень в останні десятиліття показав, що частота гострих алкогольних психозів в останні роки збільшується на всьому пострадянському просторі, а за даними досліджень В. Н. Кузьмінова, в Україні їх кількість щорічно зростає на 10-15 \% [20]. Це свідчить про постійне збільшення групи ризику осіб, які становлять потенційну суспільну небезпеку щодо скоєння тяжких СНД у зв'язку із систематичним зловживанням алкоголем. Крім того, прогресування алкоголізму призводить не лише до виникнення гострих алкогольних психозів, але й до зростання особистісних змін та алкогольної деградації особи. I те, й інше є фактором ризику скоєння тяжких СНД як у стані алкогольного сп'яніння, так і поза ним, коли на перший план виступають особистісні розлади та антисоціальні тенденції. Всі хворі на алкоголізм, у яких виникають гострі алкогольні психози, являють високу суспільну небезпеку. До основних опосередкованих криміногенних чинників у хворих на алкоголізм 3 алкогольними психозами слід відносити початок зловживання алкоголем у молодому віці, низьку соціальну адаптацію, а також небажання хворих лікуватися від алкоголізму.

Психічні порушення у жінок, зумовлені вживанням алкоголю, можуть відображатися на вчинках сп'янілих під час скоєння ними правопорушень, вважає I. В. Левенець [11]. Насамперед психічні порушення відбиваються в психічній неврівноваженості, емоційній нестійкості, подразливості, швидкому переключенні уявлень у рухові акти, спробах передчасної реалізації виниклих намірів і загальному психомоторному збудженні. У практиці експертизи спостерігаються стани звичайного алкогольного сп'яніння 3 істеричними явищами (фантазуванням, вигадками, самозвинуваченнями та ін.), елементами перебільшення, бешкетування, розпусності тощо. Відношення оточуючих (С Шаповалов В. В., Шаповалов В. В., Шаповалова В. О., Радіонова В. О., 2015 
завжди відбивається на поведінці i характері дій сп’янілих. Так, вони, наштовхуючись на активну протидію з боку оточуючих, часто докорінно змінюють свою поведінку, намагаються виправдовуватись, уникнути відповідальності. Таким чином, психічні зміни, що виникають в результаті дії алкоголю, відбиваються на вчинках сп’янілих і формуванні в них задуму, характеру виконання злочину. Разом із тим у стані звичайного алкогольного сп’яніння немає тієї сукупності ознак, які властиві сутінковому розладу свідомості. Це свідчить, що психічні розлади при звичайному сп'янінні не можуть бути ототожнені з психотичними розладами. У деяких випадках при скоєнні злочину в стані звичайного сп'яніння здатність особи розуміти свої дії й керувати ними лише ослаблюється. Все це виключає звичайне алкогольне сп’яніння в законодавстві 3 тих психотичних розладів, які обумовлюють неосудність. У карне законодавство введено норму про те, що особа, яка скоїла злочин у стані сп'яніння, не звільняється від кримінальної відповідальності (ст. 21 ККУ). Більше того, при визначенні покарання скоєння злочину в стані сп'яніння визнається обставиною, що обтяжує кримінальну відповідальність (п. 13 ст. 67 ККУ). Особа, яка знаходиться в патологічному сп’янінні, хворобливо сприймає оточуючу дійсність, зовнішнє середовище набуває для неї загрозливого характеру. Все це супроводжується розгубленістю, тривогою, страхом, які іноді досягають ступеню неусвідомленого жаху.

На наш погляд, шляхом вирішення проблеми зловживання алкоголем серед жінок та скоєння внаслідок цього злочинів у стані алкогольного сп'яніння (що знаходиться у причинно-наслідкових зв'язках) є вивчення та застосування в Україні Свропейського плану дій, спрямованого на скорочення шкідливого вживання алкоголю на 2012 - 2020 pр. Даний план, затверджений 53 державами-членами ВОО3, є найновішою стратегічною відповідною дією в масштабах Європейського Регіону, спрямований на зниження попиту серед жінок та чоловіків на зловживання алкоголем, рівня захворюваності i пов'язаної з ним злочинності [9]. План містить всебічний огляд проблеми та ефективної політики деяких країн, де доведено про ефективність скорочення (С Шаповалов В. В., Шаповалов В. В., Шаповалова В. О., Радіонова В. О., 2015 
попиту (культура вживання) на алкоголь та шкоду, що завдається ним, а саме: вплив на ситуацію шляхом регулювання цін на алкогольні напої; боротьба із злочинцями, які скоюють злочини, пов’язані 3 алкоголем (водіями транспортних засобів у стані алкогольного сп’яніння, керівниками та продавцями торгових мереж, що продають алкогольні напої у невстановлений час та неповнолітнім тощо). У цілому, як вважають експерти ВОО3, у країнах світу кількість пунктів продажу алкоголю має причинно-наслідкові зв'язки 3 рівнем споживання алкоголю, тенденцією до збільшення вживання алкоголю при збільшенні числа пунктів продажу та зменшення - при зменшенні числа пунктів продажу алкоголю [8]. Як запорука стримування підприємців від збільшення пунктів продажу алкоголю є збільшення податків на алкоголь, що може бути використане в Україні, як реальна стратегія кількості зменшення споживання алкоголю та кількості осіб, що його споживають, в т.ч. молоді.

Прикладом використання досвіду країн ЄC 3 протидії поширенню алкоголізму серед населення, а саме дітей та молоді, є введення депутатами Державної Думи РФ заборони на продаж в магазинах у нічний час спиртних напоїв. Зокрема, у п. 5 ст. 16 Федерального Закону від 22.11.1995 р. (ред. від 02.11.2013 р.) № 171-Ф3 «Про державне регулювання виробництва і обігу етилового спирту, алкогольної i спиртовмісної продукції і про обмеження споживання (розпивання) алкогольної продукції» зазначено наступні обмеження: «Не допускається роздрібний продаж алкогольної продукції з 23 до 8 години за місцевим часом, за винятком роздрібного продажу алкогольної продукції, здійснюваної організаціями, і роздрібного продажу пива і пивних напоїв, сидру, пуаре, медовухи, здійснюваної індивідуальними підприємцями, при наданні такими організаціями та індивідуальними підприємцями послуг громадського харчування, а також роздрібного продажу алкогольної продукції, здійснюваної магазинами безмитної торгівлі. Орган державної влади суб'єктів Російської Федерації має право встановлювати додаткові обмеження часу, умов і місць роздрібного продажу алкогольної продукції, в тому числі повну заборону на роздрібний продаж алкогольної продукції» [13]. Законодавці (С Шаповалов В. В., Шаповалов В. В., Шаповалова В. О., Радіонова В. О., 2015 
запевняють населення, що введене обмеження знизило рівень алкоголізації населення та злочинів, скоєних у стані алкогольного сп’яніння.

Слід відмітити, що у деяких країнах ЄС діють тимчасові обмеження на продаж міцного алкоголю в магазинах: Великобританія, Ірландія, Іспанія, Данія, Латвія, Литва, Македонія, Нідерланди, Норвегія, Словенія, Фінляндія, Швеція [52-54]. Окремо слід нагадати, що в таких країнах Близького Сходу, як OAE, Саудівська Аравія, Сгипет, Пакистан, діють жорстокі закони, що базуються на Шаріаті щодо осіб, які знаходяться в стані алкогольного сп’яніння у людних місцях або скоїли злочини у стані алкогольного сп’яніння [25-27]. Тому жінки в цих країнах є запорукою цнотливості, добропорядності, добробуту та сімейного вогнища. Проте в Пакистані чиновники та лікарі наголошують на тому, що одним із проблемних питань є зловживання алкоголем мусульманами. Крім того, у цій країні спостерігаються: динаміка зростання кількості осіб, що зловживають алкоголем (+10\% за 5 років); факти зловживання алкоголем разом 3 наркотичними засобами, як серед заможного, так і серед бідного населення; проблеми 3 якістю саморобних алкогольних напоїв (наприклад, в Пакистані спочатку готують дві форми лікерів: «kupрі» та «tharra», а потім їх змішують для збільшення ефекту), внаслідок чого в м. Карачі у 2007 р. від отруєння «коктейлями» загинуло 22 особи, а в м. Фейсалабад у 2013 p. - 18 осіб [28; 10]; проблема щодо поміщення до реабілітаційних клінік жінок, які страждають на алкоголізм та тривалий час займалися вихованням дітей; проблема доведення у доступній формі пацієнтамрадіослухачам лікарями-психіатрами через спілкування у прямому ефірі на радіо-FM важливості запобігання розвитку алкогольної залежності та боротьби 3 існуючою залежністю. Важливо також зазначити, що мірою покарання за вживання алкоголю мусульманами є штраф у розмірі 80 ударів батогом.

На нашу думку, саме обмеження в часі комерційного обігу - просування (продажу) алкогольних напоїв (у т.ч. пиво, слабоалкогольні напої - «лонгер», «шейк», «бренді-кола» тощо), а також виведення алкогольних відділів у супермаркетах до ізольованих приміщень, куди заборонено заходити особам до 21 (С Шаповалов В. В., Шаповалов В. В., Шаповалова В. О., Радіонова В. О., 2015 
року, вагітним жінкам та особам у стані алкогольного сп'яніння, є основними i найважливішими кроками у боротьбі 3 алкоголізацією населення країни та профілактикою злочинів, що скоюють у стані алкогольного сп’яніння. Ці кроки ми пропонуємо закріпити в Законі України «Про державне регулювання виробництва і обігу спирту етилового, коньячного і плодового, алкогольних напоїв та тютюнових виробів», що є важливим заходом профілактики причин i умов, які спричиняють скоєння злочинів у стані алкогольного сп'яніння, а також належним рівнем боротьби (культура вживання) 3 надмірним зловживанням жінками алкоголю та шкідливими наслідками для них та їхнього оточення [13]. Тобто до ст. 15 «Імпорт, експорт, оптова i роздрібна торгівля алкогольними напоями та тютюновими виробами» зазначеного вище Закону України ми пропонуємо внести редакційні зміни, наведено в таблиці.

Таблиця

Зміни до ст. 15-3 Закону України «Про державне регулювання виробництва і обігу спирту етилового, коньячного і плодового, алкогольних напоїв та тютюнових виробів» [13]

\begin{tabular}{|c|c|}
\hline \multicolumn{2}{|c|}{$\begin{array}{c}\text { Стаття 15-3 «Обмежсення щодо продажу пива (крім безалкогольного), алкогольних, } \\
\text { слабоалкогольних напоїв, вин столових та тютюнових виробів» }\end{array}$} \\
\hline Чинна редакиія статті & Запропоновані редакиійні зміни \\
\hline Забороняється продаж пива (крім & пункт 1 викласти у такій редакції: \\
\hline безалкогольного), алкогольних, слабоалког & «особами, які не досягли 21 року»; \\
\hline $\begin{array}{l}\text { напоїв, вин столових та тютюнових вироб } \\
\text { 1) особами, які не досягли } 18 \text { років; } \\
\text { 2) особам, які не досягли } 18 \text { років; } \\
\text { 3) у приміщеннях та на території навчал }\end{array}$ & $\begin{array}{l}\bullet \quad \text { пункт } 2 \text { викласти у такій редакції: «особам, } \\
\text { які не досягли } 21 \text { року»; } \\
\text { додати наступні пункти: } \\
\text { «12) у період доби з } 21.00 \text { до } 9.00 \text { години (за }\end{array}$ \\
\hline закладів, зак. & бдажу алкогольних напоїв на ро \\
\hline Іходять & дляспожи \\
\hline 4) у приміщеннях спеціалізованих торговельних & ння громадського харчування та \\
\hline організацій, що здійснюють тс & щчо мають статус \\
\hline дитячого асортименту а & суб'сктів господарювання громадського \\
\hline також у відповідних відді & харчування, підприємств з універсальним \\
\hline універсальних торговельн & асортиментом товарів); \\
\hline 5) у закритих спортивних сп & 13) в парках, скверах, неподалік \\
\hline ковій тарі); & на пляжсах; \\
\hline оргових автоматів; & 14) в нестаціонарних торгівельних об’єктах, \\
\hline 7) на полицях самообслуговування (крім & торгових точках без контрольно-касової техніки \\
\hline тютюнових виробів у блок & 15) за дві години до початку масових заходів, \\
\hline $\begin{array}{c}\text { слабоалкогольних напоїв, вин столових, пива); } \\
\text { 8) поштучно (для тютюнових виробів, крім }\end{array}$ & $\begin{array}{l}\text { протягом проведення та протягом двох годин } \\
\text { після закінчення масових заходів у торгових }\end{array}$ \\
\hline сигар); & закладах, шо знаходяться на відстані ближче \\
\hline 9) у споживчих упаковках, що містять менш & n’яти кілометрів від місия проведення масового \\
\hline сигарет; & заходу; \\
\hline 10) з рук; & 16) в місиях масового перебування громадян; \\
\hline 11) у невизначених для цього місцях торгівлі & 17) на зупинках громадського транспорту» \\
\hline
\end{tabular}

(С Шаповалов В. В., Шаповалов В. В., Шаповалова В. О., Радіонова В. О., 2015 
Підвищена увага до осіб, що страждають на алкоголізм, під час проходження ними планових та позапланових медичних оглядів, інших звернень до лікаря (проведення профілактичних бесід щодо шкоди алкоголю; направлення на лікування до наркологічних диспансерів, у разі необхідності примусове), на наш погляд, також є важливим та обов'язковим кроком на шляху боротьби 3 алкогольними захворюваннями та злочинами, які вчинюються на такій основі.

Таким чином, судово-фармацевтичне вивчення фактів убивств, вчинених жінками у стані алкогольного сп'яніння на криміналістичних засадах свідчить про те, що в Україні гостро стоїть проблема жіночого алкоголізму. Крім того, ця проблема гостро стоїть у країнах ЄС та Близького Сходу, як для чоловіків, так і для жінок. Тому іі вирішення знаходиться у площині удосконалення законодавства щодо обмеження доступу до алкоголю всіх верств населення України на прикладі мусульманських країн. Досвід інших країн свідчить про необхідність внесення змін та доповнень до деяких Законів України, що призведе до введення обмежень комерційного просування алкогольних напоїв протягом доби, а саме: заборона їх продажу з 21.00 до 9.00 години; заборона розміщення вітрин, полиць 3 алкогольними напоями в одному торговому залі поряд 3 іншою продукцією: розміщувати необхідно у відокремленому приміщенні, доступ до якого обмежений певним категоріям громадян. Крім того, необхідний подальший розвиток міждисциплінарних зв'язків між кримінальним правом, криміналістикою, медичним та фармацевтичним правом.

\section{Список літератури:}

1. Алкоголь и здоровье : доклад о ситуации в 35 европейских странах, 2013 г. [Электронный ресурс] / Официальный сайт Европейского регионального бюро ВОЗ. - Режим доступа : : http://www.euro.who.int/ru/health-topics/disease-prevention/alcoholuse/publications/2013/status-report-on-alcohol-and-health-in-35-european-countries-2013.

2. Борисов B. I. Нормативне зазначення закону про кримінальну відповідальність у контексті новел кримінального процесуального законодавства України / В. І. Борисов // Наука кримінального права в системі міждисциплінарних зв'язків : матеріали міжнар. наук.практ. конф., 9-10 жовт. 2014 р. - Х. : Право, 2014. - С. 326-330.

3. Вживання алкоголю у віці 15-19 років, всі країни [Електронний ресурс] // База даних Свропейського бюро ВООЗ - 19.01.2015. - Режим доступу : http://apps.who.int/gho/data/node.main-euro.A1214?lang=en\&showonly=GISAH. 
4. Возможно ли употреблять алкоголь без вреда для моего здоровья: вопросы и ответы [Электронный ресурс] / Европейское региональное бюро ВОЗ. - 20.01.2015. - Режим доступа : http://www.euro.who.int/ru/health-topics/disease-prevention/alcohol-use/data-andstatistics/q-and-a-how-can-i-drink-alcohol-safely.

5. Волошин П. В. Тенденції розвитку психіатричної допомоги населенню на основі принципів фармацевтичного і медичного права в Україні / П. В. Волошин // Український вісник психоневрології. - 2014. - Т. 22, вип. 2, дод. - С. 296.

6. Всеобщая декларация прав человека, принята резолюцией 217 A (III) Генеральной Ассамблеи ООН от 10.12.1948 г. [Электронный ресурс]. - Режим доступа : http://www.un.org/ru/documents/decl_conv/declarations/declhr.

7. Геронтологические аспекты современных форм алкогольной зависимости / И. К. Сосин, Ю. Ф. Чуев, Н. А. Пересадин, И. М. Скалыга // Український вісник психоневрології. - 2014. - Т. 22, вип. 2, дод. - С. 209-214.

8. Гурина И. Л. Ограничения на алкоголь в Дубае: можно ли пить туристам [Электронный ресурс] / И. Л. Гурина. - 27.01.2015. - Режим доступа : http://alko03.ru/zakon-iporyadok/mozhno-li-pit-alkogol-v-dubae.html.

9. Дорослі жителі Європи вживають в середньому три стандартні дози алкогольних напоїв щоденно [Електронний ресурс] // Центр ЗМІ Європейського регіонального бюро ВООЗ. - 27.03.2012. - Режим доступу : http://www.euro.who.int/ru/mediacentre/sections/press-releases/2012/03/adults-in-europe-consume-three-standard-alcoholic-drinksper-day-on-average.

10. Жінка, яка через ревнощі вбила свого коханого, відправилась за грати [Електронний ресурс] / ВЗГ ГУМВС України в Харківській області. - 28.05.2014. - Режим доступу : http://mvs.gov.ua/mvs/control/kharkiv/uk/publish/printable_article/116602.

11. Закон України «Основи законодавства України про охорону здоров’я» // Відом. Верхов. Ради України. - 1993. - № 4. - Ст. 19.

12. Закон України «Про відпустки» // Відом. Верхов. Ради України.-1997.-№2.-

Ст.4.

13. Закон України «Про державне регулювання виробництва i обігу спирту етилового, коньячного і плодового, алкогольних напоїв та тютюнових виробів» від 19.12.1995 p. №481/95-ВP [Електронний ресурс]. Р- Режим доступу : http://zakon2.rada.gov.ua/laws/show/481/95-вp/page3.

14. Закон України «Про лікарські засоби» // Відом. Верхов. Ради України. - 1996. № 22. - Ст. 86 .

15. Закон України «Про охорону праці» // Відом. Верхов. Ради України. - 1992. №49. - Ст. 668.

16. Закон України «Про сприяння соціальному становленню та розвитку молоді в Україні» // Відом. Верхов. Ради України. -1993. - № 16.-Ст. 167.

17. Комитет экспертов ВО3 по проблемам, связанным с потреблением алкоголя. Второй доклад. - Женева : ВОЗ, 2007. - 67 с.

18. Конвенція «Про права дитини» від 20.11 .1989 р. // Зібрання чинних міжнародних договорів України. - 1990. - № 1. - С. 205.

19. Конституція України від 28.06.1996 р. // Відом. Верхов. Ради. - 1996. - № 30. $48 \mathrm{c}$.

20. Криміналістика: питання і відповіді : навч. посіб. // А. В. Кофанов, О. Л. Кобилянський, Я. В. Кузьмічов та ін. - К. : Центр учбової літератури, 2011. - 280 с.

21. Криміналістика : підруч. / В. Ю. Шепітько, В. О. Коновалова, В. А. Журавель та ін. ; за ред. проф. В. Ю. Шепітька. - 4-е вид., перероб. і доп. - Х. : Право, 2008. — 464 с.

22. Кримінальний процесуальний кодекс України. Науково-практичний коментар : у 2 т. / за заг. ред. В. Я. Тація, В. П. Пшонки, А. В. Портнова. - Х. : Право, 2012. - Т. 1. - 768 c.; Т. 2. -664 c. 
23. Кримінальний процесуальний кодекс України [Електронний ресурс]. - Режим доступу : http://zakon1.rada.gov.ua/laws/show/4651\%D0\%B0-17.

24. Кузнецова T. В. Лікарське забезпечення терапії алкогольної залежності: автореф. дис. на здобуття наук. ступеня канд. фармац. наук : спец. 15.00 .01 «Технологія ліків та організація фармацевтичної справи» / Т. В. Кузнецова. - К., 2006. - 24 с.

25. Левенещь I. В. Судова психіатрія : навч. посіб. [Електронний ресурс] / I. B. Левенець. - Тернопіль : Економічна думка, 2005. - 328 с.

26. Линский И. В. Генетические, средовые и судебно-фармацевтические детерминанты развития состояний зависимости в условиях современной Украины / И. В. Линский, А. И. Минко, Валентин В. Шаповалов // Український вісник психоневрології. 2014. - Т. 22, вип. 2, дод. - С. 325-331.

27. Линский И. В. Детским психиатрам о пьянстве детей и подростков [Электронный ресурс] / И. В. Линский // Новости украинской психиатрии. - К.-Х., 2014. Режим доступа : http://www.psychiatry.ua/articles/paper438.htm.

28. Марута H. А. Принципи фармацевтичного і медичного права як запорука вчасного доступу до лікарських засобів та психіатричної допомоги всіх верств населення / Н. А. Марута // Український вісник психоневрології. - 2014. - Т. 22, вип. 2, дод. - С. 297.

29. Мельник A. B. Соціальні характеристики хворих, які скоїли суспільно небезпечні дії на час гострих алкогольних психозів [Електронний ресурс] / А. В. Мельник // Актуальные вопросы современной психиатрии и наркологии : сб. науч. работ Ин-та неврол., псих. и нарк. АМН Украины и Харьк. обл. клин. психіатр. больн. № 3 (Сабуровой дачи). - К.X., 2010. - T. 5. - Режим доступу : http://www.psychiatry.ua/books/actual/paper066.htm.

30. Минко А. И. Алкоголизм - междисциплинарная проблема (выявление, лечение, реабилитация, профилактика) [Электронный ресурс] / А. И. Минко // Український вісник психоневрологіi. - 2001. - Т. 9, вип. 4. - С. 6-7. - Режим доступа : http://www.psychiatry.ua/articles/paper059.htm.

31. Минко A. И. Проблемы в связи с употреблением алкоголя (в практике семейного врача) / А. И. Минко, И. В. Линский // Новости медицины и фармации. - 2010. № 15 (35). - C. $8-10$.

32. На Вінниччині суд виніс вирок жінці, яка задушила свого співмешканця [Електронний ресурс] // СЗГ УМВС України у Вінницькій області. - 13.11.2014. - Режим доступу

http://mvs.gov.ua/mvs/control/kharkiv/uk/publish/article/img/kharkiv/uk/publish/printable_article/1 226783.

33. Наказ МО3 України від 01.08 .2000 р. № 188 «Про затвердження таблиць невеликих, великих та особливо великих розмірів наркотичних засобів, психотропних речовин і прекурсорів, які знаходяться у незаконному обігу» // Офіційний вісник України. 2000. - № 34. - C. 162.

34. Наказ МОЗ України від 17.01.1995 р. № 6 «Правила судово-медичного визначення ступеня тяжкості тілесних ушкоджень» [Електронний ресурс]. - Режим доступу: http://zakon0.rada.gov.ua/laws/show/z0255-95.

35. Наказ МО3 України від 19.07.2005 р. № 360 «Про затвердження Правил виписування рецептів та вимог-замовлень на лікарські засоби і вироби медичного призначення, Порядку відпуску лікарських засобів і виробів медичного призначення з аптек та їх структурних підрозділів, Інструкції про порядок зберігання, обліку та знищення рецептурних бланків та вимог-замовлень» // Офіційний вісник України. - 2005. - № 29. - С. 452. - Ст. 1745.

36. Наказ МО3 України від 21.01.2010 р. № 11 «Про затвердження Порядку обігу наркотичних засобів, психотропних речовин та прекурсорів у закладах охорони здоров'я України» // Офіційний вісник України. - 2010. - № 43. - С. 99.

37. Панов M. I. Системний підхід у дослідженні науки кримінального права та іï міждисциплінарних зв'язків / М. І. Панов // Наука кримінального права в системі (С Шаповалов В. В., Шаповалов В. В., Шаповалова В. О., Радіонова В. О., 2015 
міждисциплінарних зв'язків : матеріали міжнар. наук.-практ. конф., 9-10 жовт. 2014 р. - Х. : Право, 2014. - С. 7-13.

38. Пат. 10109 А Україна, МКИ5 А 61К 9/20. Дитячий лікарський засіб «Валькофен» / В. О. Шаповалова, В. П. Черних, В. О. Заболотний, В. В. Шаповалов ; опубл. 30.09.96, Бюл. № 3 .

39. Постанова КМУ «Про затвердження переліку наркотичних засобів, психотропних речовин і прекурсорів» від 06.05.2000 р. № 770 // Офіційний вісник України. 2000. - №19.-C.91.

40. Правоохоронці затримали кіровоградку, яка підозрюється у вбивстві родича [Електронний ресурс] / Кіровоградський МВ УМВС України в Кіровоградській області. 17.11.2014. Режим http://mvs.gov.ua/mvs/control/kirovohrad/uk/publish/article/115263.

41. Сімейний кодекс України // Відом. Верхов. Ради України. - 2002. - № 21. - Ст. 135.

42. Судебная фармация, фармацевтическое право и медицинское право как инструмент МЗ Украины и МВД Украины в изучении фактов убийств и самоубивств вследствие употребления психоактивных веществ или несвоевременной медикофармацевтической помощи / В. В. Шаповалов, В. А. Шаповалова, А. М. Мельниченко и др. // Ліки України. - 2007. - № 112, дод. - С. 170-179.

43. Тонков E. E. Доверие населения к государству - необходимое условие эффективного противодействия преступности [Электронный ресурс] / Е. Е. Тонков // Научные ведомости Белгородского государственного университета. - 2007. - № 2 (33). Режим доступа http://dspace.bsu.edu.ru/bitstream/123456789/1799/1/Tonkov\%20E.E.\%20Doverie\%20naseleniaya. pdf.

44. Фармацевтичне право : навч. посіб. до аудиторної та поза аудиторної роботи 3 фармацевтичного законодавства за спеціальністю «Фармація»/ за ред. В. О. Шаповалової, В. В. Шаповалова, В. В. Шаповалова (мол.). - Х., 2008. - 144 с.

45. Федеральный Закон Российской Федерации «О государственном регулировании производства и оборота этилового спирта, алкогольной и спиртосодержащей продукции и об ограничении потребления (распития) алкогольной продукции» от 22.11.1995 г. №171-Ф3 (ред. от 02.11.2013г.) [Электронный ресурс]. - Режим доступа : http://www.referent.ru/1/206281.

46. Цивільний кодекс України // Відом. Верхов. Ради України. - 2003. - №40. - Ст. 356.

47. Alkoholisko dzērienu aprites likums. Likums Saeimā pieṇemts 2004.gada 22.aprīlī. [Electronic resource]. - Access : http://likumi.lv/doc.php?id=88009.

48. Johnson T. Islam: Governing Under Sharia [Electronic resource] / T. Johnson, M. Aly Sergie // Council on Foreign Relations. - 25.07.2014. - Access : http://www.cfr.org/religion/islam-governing-under-sharia/p8034.

49. Levchuk N. Alcohol and mortality in Ukraine. Institute for Demography and Social Studies at the National Academy of Sciences of Ukraine [Electronic resource] / N. Levchuk. Access : http://www.academia.edu/1521860/Alcohol_and_mortality_in_Ukraine.

50. Lietuvos Respublikos Alkoholio kontrolès įstatymas $19 \overline{9} 5 \mathrm{~m}$. balandžio $18 \mathrm{~d}$. Nr. I857 Vilnius [Electronic resource] // Žin. - 2004. - Nr. 47-1548. - Access : http://www3.lrs.lt/pls/inter2/dokpaieska.showdoc_1?p_id=400001.

51. Pakistan alcohol tragedy kills 22 [Electronic resource] // BBC. - 21.09.2007. Access : http://news.bbc.co.uk/2/hi/south_asia/7006045.stm.

52. Pakistan battles growing alcohol addiction [Electronic resource] // BBC. 16.09.2013. - Access : http://www.bbc.co.uk/news/world-asia-24044337.

53. Toxic Pakistan alcohol claims 18 lives [Electronic resource] // BBC. - 28.07.2013. Access : http://www.bbc.com/news/world-asia-23481391.

(С Шаповалов В. В., Шаповалов В. В., Шаповалова В. О., Радіонова В. О., 2015 
54. Zakon Republike Slovenije «O omejevanju porabe alkohola (ZOPA)» [Electronic resource]. - Access : http://www.uradni-list.si/1/content?id=41062.

Шаповалов В. В., Шаповалов В. В., Шаповалова В. А., Радионова В. А. Судебнофармацевтическое и криминалистическое изучение фактов убийств, совершенных женщинами в состоянии алкогольного опьянения

Проведен судебно-фармачевтический анализ фактов убийств, совершенных женщинами в состоянии алкогольного опьянения на основе криминалистики. Установлено, что в странах ЕС, Ближнего Востока и в Украине остро стоит проблема алкоголизма, как среди мужчин, так и среди женщин. Выяснено, что решение данной проблемь в Украине находится в плоскости совершенствования законодательства относительно ограничения доступа к алкоголю всех слоев населения на примере мусульманских стран. Кроме того, необходимо дальнейшее развитие междисииплинарных связей между уголовным правом, криминалистикой, медицинским и фармацевтическим правом.

Ключевые слова: судебная фармация, криминалистика, убийство, женщина, алкоголь.

Shapovalov V. V., Shapovalov V. V., Shapovalova V. O., Radionova V. O. Forensic, pharmaceutical and criminalistics examination of the facts of murders committed by women in intoxicated state.

The article presents a forensic and pharmaceutical examination of the facts of murders committed by women in drunk state on criminalistics principles. Established that in the EU, the Middle East and Ukraine acute problem of alcoholism among men and women. Shown that the solution of this problem in Ukraine is in the plane of the improvement of legislation to limit access to alcohol for all population as an example of Muslim countries. Also needed the further development of interdisciplinary connections between criminal law, criminology, medical and pharmaceutical law.

Keywords: forensic pharmacy, criminalistics, murder, woman, alcohol. 


\section{Розширена анотація}

статті Шаповалова Валерія Володимировича, Шаповалова Валентина

Валерійовича, Шаповалової Вікторії Олексіївни, Радіонової Вікторії

Олександрівни на тему: «Судово-фармацевтичне та криміналістичне вивчення фактів убивств, скоєних жінками у стані алкогольного сп'яніння»

Shapovalov V.V., Doctor of Pharmacy, professor, Head of pharmacy management of medical and pharmaceutical activities of the Department of Health of the Kharkiv regional state administration, Kharkiv

Shapovalov V.V., Candidate of Pharmaceutical Sciences, assistant professor of medical and pharmaceutical law, and general clinical pharmacy Kharkiv Medical Academy of Postgraduate Education, a lawyer, Kharkiv

Shapovalova V.O., Doctor of Pharmacy, professor, Head of the department of medical and pharmaceutical law, and general clinical pharmacy Kharkiv Medical Academy of Postgraduate Education, Kharkiv

Radionova V.A., Candidate of Pharmaceutical Sciences, assistant professor of medical and pharmaceutical law, and general clinical pharmacy Kharkiv Medical Academy of Postgraduate Education, Kharkiv

An extended abstract of a paper on the subject of:

«Forensic, pharmaceutical and criminalistics examination of the facts of murders committed by women while intoxicated»

Problem setting. In Ukraine from the very beginning people thought, that the woman is the homemaker, wealth, inheritance, child health and gene pool of the nation, which is the foundation of a healthy family and society. Therefore, from a woman, of her health, the opportunity to realize their aspirations in the implementation of labor and social activities depends on the health of each individual family and society as a whole. In recent decades, the role of women has changed: a mother and 
homemaker, she has become an active public figure that feels high physical and psychological pressure.

Recent research and publication analysis. According to researches of the Sosin I.K., Linsky I.V., Minko A.I., Voloshin P.V., Maruta N.O., Chuev Y.F., Melnik A.V. on the examples of clinical practice proved that the female body is weaker than men's and, unlike the latter, not accustomed to long and excessive abuse of alcohol. That is why addiction to substances among women faster than men's behavior while intoxicated - aggressive and treatment of female alcoholism and drug addiction are longer and harder.

Paper objective. The aim of the paper was to study the statistical data from the WHO and the Department of Healthcare of Kharkiv Regional State Administration regarding the incidence of alcoholism among young people in the European Union and the level of alcohol consumption among women in Ukraine, the study of forensic and pharmaceutical facts concerning the murders committed by women in intoxicated state and on the examples to show the damage that causes irregular drink of alcohol to the human and its associates, generalization of legal acts and proposals to reduce alcohol circulation and increase the women's access to certain types of drugs.

Paper main body. Based on examples from forensic and pharmaceutical practice found that women in drunk state commit illegal acts that are criminal offenses resulting in suffering her family and children, and the state holds the social and financial burden and severe financial losses aimed at its treatment and medical supply all legal classification groups. According to the results of forensic and psychiatric research by the Linsky I.V., Minko A.I. and Shapovalov Val.V. established causal relationships and positive relationship between the number of alcoholic psychoses, drug-addicts and the number of crimes committed on the territory of Ukraine in general and in the Kharkiv region in particular. That is, women with signs of alcohol dependence, and continued abusing of the psychoactive substance alcohol are often the victims or perpetrators of various offenses committed by intoxicated.

Conclusions of the research. Forensic and pharmaceutical examination of the facts of murders committed by women in drunk state based on criminalistics principles 
shows that in Ukraine acute problem of female alcoholism. In addition, the problem is acute in the EU and the Middle East, both for men and women. Therefore, its solution is in the plane of the improvement of legislation to limit access to alcohol for the population of Ukraine as an example of Muslim countries. Experience in other countries shows the need for amendments to certain laws of Ukraine, which would impose a limitation commercial promotion of alcoholic beverages during the day, namely a ban on the sale from $9.00 \mathrm{pm}$ to $9.00 \mathrm{am}$; prohibition of placing windows, shelves with alcohol on a trading floors, along with other products, they should be placed in a secluded room, access to which is restricted to certain categories of people. Also needed the further development of interdisciplinary connections between criminal law, criminology, medical and pharmaceutical law. 